\title{
What prevails in climatic response of Pinus sylvestris in-between its range limits in mountains:
} slope aspect or elevation?

\author{
Dina F. Zhirnova ${ }^{1}$, Liliana V. Belokopytova ${ }^{1}$, Anna E. Barabantsova ${ }^{2}$, \\ Elena A. Babushkina, ${ }^{1, *}$, and Eugene A. Vaganov ${ }^{3,4}$ \\ ${ }^{1}$ Khakass Technical Institute, Siberian Federal University, 27 Shchetinkina, 655017, Abakan, Russia \\ ${ }^{2}$ National park 'Shushensky Bor', 9 Lugovaya, 662710, Shushenskoe, Russia \\ ${ }^{3}$ Siberian Federal University, 79 Svobodny, 660041, Krasnoyarsk, Russia \\ ${ }^{4}$ Sukachev Institute of Forest, Siberian Branch of the Russian Academy of Sciences, 50/28 \\ Akademgorodok, 660036, Krasnoyarsk, Russia \\ Corresponding author: Elena A. Babushkina, <babushkina70@ mail.ru>
}

\begin{abstract}
The roles of slope orientation and elevational temperature gradient were investigated for Scots pine (Pinus sylvestris L.) growth in the middle of its growth range, where these factors can significantly modulate microclimate and thus plant growth. We assumed that slope orientation causes more complex and severe effects than elevation, because it influences all three main factors of plant growth: light, heat and moisture. In addition to the total ring width, the earlywood and latewood width and latewood ratio were considered as variables that contain information about tree ring growth during the season and wood structure over all tree lifespan on three sampling sites at different elevations and opposite slopes.

Despite the observed dependence of pine growth rate on temperature and solar radiation, the mean latewood ratio is stable and similar between all sampling sites, being presumably defined by the genotype of individual trees. The seasonality of the climatic response of trees growth is bound to spatiotemporal variation of the vegetative season timing due to the elevational temperature lapse and local warming. However, its direction is primarily defined by slope orientation, where southern slope is moisture-limited, even at adjacent sites, and divergent climatic reactions of earlywood (weak moisture-limited in the last decades) and latewood growth (temperature-limited) was revealed on the northern slope.
\end{abstract}

Keywords: mountains; slope aspect; elevation; Pinus sylvestris; tree-ring width; growth-climate relationship. 


\section{Introduction}

The reaction of forests to climate change at the scale of an ecosystem is not uniform because it can be modified by the influence of nonclimatic factors. In mountain ecosystems, this influence is more variegated (Price et al. 2013); thus they can be considered as indicators of the environmental consequences of climatic change (Becker and Bugmann 2001; Anderson and Goulden 2011; Kelsey et al. 2018). Large elevation differences in mountains are inextricably linked to climatic gradients, i.e., the temperature lapse and frequent increase in precipitation with elevation (Barry 1992; Price et al. 2013). In addition, due to the heterogeneous mosaic landscape in mountains, microclimate can drastically vary, which affects the growth and development of mountain vegetation (McCutchan 1983; Barber et al. 2000; Kulagin et al. 2006; Körner 2009; Monnier et al. 2012; Babushkina and Belokopytova 2014). The climatic response of plants depends on the slope spatial orientation (Kirchhefer 2000; Cai and Liu 2013; Zhang et al. 2015; Montpellier et al. 2018). The aspect and the steepness of a slope regulate the received direct solar radiation, which is an essential heat source (Deng et al. 2013; Tognetti and Palombo 2013; Wypych et al. 2018). This leads to changes in thermal and water balances at the site despite the same air temperature: direct sunlight increases the surface temperature, thus increasing moisture loss via evapotranspiration (Chen et al. 1999; Karlsson and Pomade 2013; Kirkham 2014). Therefore, it is possible in mountain ecosystems to expect ambiguous reactions of vegetation to temperature and precipitation on slopes of different orientations, even at very close distances (Lyi et al. 2016; Latreille et al. 2017).

Tree ring width integrates the influence of the entire complex of environmental conditions. However, three basic factors - light, heat and moisture - primarily define the kinetics of plant physiological processes, including respiration, photosynthesis and growth (Fritts 1976; Schulze et al. 2005; Schulze and Mooney 2012). Exact assessment of tree ring formation kinetics during the season is possible only by direct observations of xylogenesis (Rossi et al. 2009; Balducci et al. 2016). The labor-intensity of such research, the difficulty of its execution in mountains, and the impossibility of retrospective analysis are practical restrictions on its use. On the other hand, the variables of radial growth measured by a simple standard technique, such as widths of earlywood and latewood and their ratio (portion in the tree ring), are easy indicators of the influence of climatic factors on the growth of trees during the entire duration of their lifespan (Lebourgeois 2000; Miina 2000; Oberhuber and Kofler 2000; Lebourgeois et al. 2010). The formation of earlywood and latewood clearly is temporally divided during the season. This transition is regulated by temperature and photoperiod directly (Bauerle et al. 2012; Drew and Downes 2015) or indirectly, via redirection of soluble carbohydrates to the formation of more resource-intensive thick-walled latewood cells (Rossi et al. 2009; Carteni et al. 2018) at the completion of shoot primary growth (Gyllenstrand et al. 2007; Cooke et al. 2012); however, it also depends on intrinsic genetic factors (Zobel and Jett 2012). Earlywood and latewood 
widths thus contain information about external conditions before and after this transition, as well as about process of the transition itself.

In Southern Siberia, the largest area of forests is located in mountains because of the lack of moisture for tree growth on plains (Tupitsyna 2016). However, most of forest area is not under the extreme dry or cold conditions of the forest boundaries but has a milder environment where tree growth - climate relationship is less studied. Therefore, understanding of the reaction of trees to climate change between their upper and lower distribution limits is especially relevant for regional forest management (Tchebakova et al. 2003, 2010). In this research on the example of Scots pine (Pinus sylvestris L.), one of the widespread species in the region, the investigated question was how climatic reactions of tree growth in the middle of a species range are modified by the specific landscape conditions of elevation and slope orientation. We assumed that in our study region, the change of solar radiation due to slope orientation can modulate microclimate and tree growth much more than elevational temperature gradient. To test this supposition, we compared the strength and seasonality of pine climatic response of tree growth variables at different elevations and opposite slopes.

\section{Materials and Methods}

The study was conducted on the northern margin of the Western Sayan Mountains (Online Resource, Fig. S1a) in the range of elevations from 500 to $950 \mathrm{~m}$ a.s.1. (the distribution range of Scots pine in this area is from $\sim 250$ to $1350 \mathrm{~m}$ a.s.l.). Soils are loamy, thin and stony. The climate is sharply continental (Alisov 1956). In the foothills (300-350 $\mathrm{m}$ a.s.l.), temperatures are negative from November to March, with an average temperature of $5-11^{\circ} \mathrm{C}$ below zero and $50-90 \mathrm{~mm}$ of precipitation. During the warm season (April-October), the average temperature is $11-13^{\circ} \mathrm{C}$ above zero, with 360-540 $\mathrm{mm}$ of precipitation. With elevation increase, temperature lapses approximately by $0.6^{\circ} \mathrm{C}$ per $100 \mathrm{~m}$ during period of positive temperatures, but the lapse rate decreases in winter due to temperature inversion occurrences (Monserud and Tchebakova 1996; Stepanov 2006). Precipitation has opposite gradient: approximately three times more precipitation occurs at the treeline (1300-1400 $\mathrm{m}$ a.s.1.) than at the foothills, with an approximate increase of 100-200 $\mathrm{mm}$ per $100 \mathrm{~m}$ (Polikarpov and Nazimova 1963). During the period of instrumental climatic observations, precipitation did not significantly change, but a temperature increase was observed of 0.2 and $1.1^{\circ} \mathrm{C}$ per decade during warm and cold seasons, respectively. Comparison of climatic series from regional weather stations showed that local climate was influenced by dam construction and the filling of the SayanoShushenskoe Reservoir during 1976-1990, which lead to an enhanced increase of winter temperatures (Fig. S1b; Kosmakov 2001; Babushkina et al. 2018). 
For this study we used mean temperature and amount of precipitation retrieved from the Cheryomushki weather station $\left(52.87^{\circ} \mathrm{N}, 91.42^{\circ} \mathrm{E}, 330 \mathrm{~m}\right.$ a.s.1.), which is located in the foothills near the Yenisei River. Additionally, temperature series from another station, Olenya Rechka $\left(52.50^{\circ} \mathrm{N}\right.$, 93.15 E, $1400 \mathrm{~m}$ a.s.1.), were compared with those of the Cheryomushki station over the period 19511975 (before dam building) to assess the seasonal dynamics of elevational temperature lapse. This is possible despite the distance between them $(\sim 100 \mathrm{~km})$ due to the uniformness of the air temperature spatial field, i.e., the very high correlations between the two stations' series (above 0.9 both for daily and monthly data; also sf. Babushkina et al. 2018), and because they are at the same latitude, in the same mountain range, and located on gentle $\left(<10^{\circ}\right)$ eastern slopes near riverbanks. On the basis of the daily data, moving climatic series with a 21-day window and 1-day step were developed. To make a middle ground between the necessity to consider rapid local climatic change and the low reliability of correlations between short time series, we used two overlapping 40-year subperiods, 1951-1990 and 1976-2015, in addition to the entire period of instrumental observations, 1951-2015.

Daily received direct + diffuse solar radiation was estimated in ArcGIS software (www.esri.com) on the base of the SRTM v3 digital terrain model at four points: in the middle of each sampling site and on the horizontal surface of the ridge top between slopes.

Wood samples (cores) were collected from living adult trees in the National park 'Shushensky Bor' at three sampling sites 3.5-4.5 km southeast of the weather station (Online Resource, Fig. S1b): in the bottom part of the south-facing slope (ShB_500S, 52.83 $\mathrm{N}, 91.45^{\circ} \mathrm{E}, 500-550 \mathrm{~m}$ a.s.1. $20-25^{\circ}$ slope angle), near the top of the same slope (ShB_900S, 52.84 N, 91.46 E, 900-950 m a.s.1., $\sim 30-35^{\circ}$ slope angle), and at the top of adjacent north-facing slope (ShB_900N, 84 ${ }^{\circ} \mathrm{N}, 91.46^{\circ} \mathrm{E}, 900-950 \mathrm{~m}$ a.s.1., $\sim 25-30^{\circ}$ slope angle). The history of the study area ensured minimization of human impact except for local climatic change. Poor logistic availability and historically low density of population made this area less convenient to use than other forested areas of the region. Therefore, logging and other forest management activities were not registered, and human activities were limited to hunting and gathering by local nomads before the $20^{\text {th }}$ century and to tourism since the mid-1960s after establishment of several settlements in the vicinity and the beginning of dam building (personal communication from Tolmachev V.A., national park director; see also Myglan 2010 and references there). The National Park was established in 1995 to regulate touristic activities.

Tree stands at the sampling sites are represented by Scots pine, Siberian larch (Larix sibirica Ledeb.), and common aspen (Populus tremula L.), with the addition of Siberian fir (Abies sibirica Ledeb.) on the northern slope. The undercover on the southern slope has a density of 20-30\% and is represented by Cotoneaster melanocarpus, Caragana arborescens, Spiraea media et al. at both elevations. On the northern slope, the undercover of 30-40\% density is composed of Viburnum opulus, Salix caprea, Cotoneaster melanocarpus, Padus avium, Ribes rubrum, Rubus idaeus et al. Both slopes 
have herb layers of $55-75 \%$ density consisting of mesophytic forbs and graminoids. The soil is alfisol with $4-9 \%$ and $8-12 \%$ of humus on southern and northern slopes, respectively. The typical snowpack is approximately $40 \mathrm{~cm}$ at the bottom of slopes and 70-80 $\mathrm{cm}$ at both top-slope sites. At both sites on the southern slope, snowmelt lasts approximately two weeks and ends at an average air temperature of 2.5-3 ${ }^{\circ} \mathrm{C}$ (ca. April 15 and April 25 at the bottom and top of the slope, respectively), whereas on the northern slope, it develops more slowly, ending on approximately May 5 at an average air temperature of ca. $4.5^{\circ} \mathrm{C}$ (personal communication from employees of the National park 'Shushensky Bor').

Collection, transportation and preparation of the cores were performed using standard techniques of dendrochronology (Cook and Kairiukstis 1990). Measurement on the LINTAB station, cross-dating and standardization of total ring width (TRW), earlywood width (EWW), and latewood width (LWW) individual series were performed with the specialized software TSAPWin, COFECHA, and ARSTAN (Holmes 1983; Rinn 2003; Cook and Krusic 2005). Transitions between earlywood and latewood were visually assessed (Meko and Baisan 2001). During standardization, long-term nonclimatic trends were fitted as cubic smoothing splines with a frequency response of 0.50 at $67 \%$ of the individual series length and then removed (Online Resource, Fig. S2). Cross-dated standard individual TRW series are shown in Online Resource, Fig. S3. Latewood ratio (LWR) series were calculated for each sample as ratios of LWW to TRW. These series have approximately linear trends (stable or slowly increasing) and were thus standardized using linear functions. Site chronologies of the four growth variables (TRW, LWW, EWW, and LWR) were developed from individual series with bi-weighted means.

In this study, we used the following statistical characteristics (Table 1): arithmetic mean; standard deviation; mean coefficient of sensitivity (the ratio of the modulus of two successive values' difference to their arithmetic mean, averaged over the entire length of the chronology); mean interserial correlation coefficient (correlation coefficient calculated between every pair of individual series at the site with a 50-year window and 25-year step and then averaged); and first-order autocorrelation coefficient. Additionally, the signal-to-noise ratio $(\mathrm{SNR}=(\mathrm{N} \cdot \mathrm{R})(1-\mathrm{R})$, where $\mathrm{N}$ is the sample size $)$ and expressed population signal (EPS) were used to estimate common signal characteristics of chronologies (Wigley et al. 1984; Cook 1985; Shiyatov 1986; Cook and Kairiukstis 1990). The climatic response of tree growth was estimated by Pearson's paired correlation coefficients with the climatic series.

\section{Results}

The sampling sites were located at different elevations and slope aspects, which provides certain patterns of local environmental conditions for tree growth. The main difference between different elevations is in the air temperatures due to temperature lapse (Fig. 1). Seasonal lapse rate dynamics from comparison of two weather stations supports literature data about the Western Sayan 
climate (Monserud and Tchebakova 1996; Stepanov 2006). Note that lapse rate has a larger variation in winter than in the warm season (April-October). The top of the slope is $2-3^{\circ} \mathrm{C}$ colder than its bottom during the warm season, a difference less pronounced $\left(1-2^{\circ} \mathrm{C}\right)$ during the cold season. Another consequence of the temperature lapse is a shorter period of tree growth at higher elevations, as temperature rises above the threshold of $+5^{\circ} \mathrm{C} \sim 14$ days later in spring and drops below it $\sim 8$ days earlier in fall. At the same time, the intra-annual dynamics curve of air temperature has the same shape as solar radiation at the latitude of the study area. Correlations between these curves are 0.8830.901 without lag and a maximum of 0.971-0.993 with a lag of 25 days (similar to Huang et al. 2008). Slope aspect and angle (steepness) drastically change insolation. For example, a steep northern slope does not receive direct solar radiation during winter (Buffo et al. 1972) but only diffuse and reflected light, which leads to $68 \%$ less insolation compared with adjacent site on the southern slope. Even at the summer solstice, when solar radiation is maximal, it is approximately $16 \%$ less on the northern slope than on the top of the southern one. A comparison of the two subperiods 1951-1990 and 19762015 shows the persistence of correlations and a lag between air temperature and solar radiation. The average length of the season of air temperature above $+5^{\circ} \mathrm{C}$ is $\sim 8$ days more for the second subperiod at both elevations, with an approximately 5-day earlier onset and a 3-day later ending.

Scots pine site chronologies and their statistical characteristics are shown in Online Resource, Fig. S5, and Table 1, respectively. At all three sites, sampled pine trees are less than 110 years old, with average ages of trees $\sim 20$ years greater on the northern slope (94 years) and approximately even in the top and bottom parts of the southern slope (75 and 72 years). Despite similar tree age, mean TRW, EWW, and LWW are quite different. Even after exclusion of the most juvenile wood by limiting statistics to the 1951-2015 period, pine grows 22-28\% slower on the northern slope than on the southern one at the same elevation; with elevation, the growth rate of trees decreases by $15-19 \%$. The proportion of earlywood and latewood in the ring is stable (Fig. 2a, b), with $69-72 \%$ of earlywood and $28-31 \%$ of latewood at the site scale. Regarding individual trees, EWW and LWW relationships with TRW are also best-fitted by simple linear regressions with a zero intercept $\left(\mathrm{R}^{2}>0.9\right.$ for earlywood and $\mathrm{R}^{2}>0.4$ for latewood). Slopes of these regression equations for individual trees represent the mean ratio of the respective zone in the ring; they are in ranges of $61-80 \%, 62-78 \%$, and $65-82 \%$ for earlywood $(20-39 \%, 22-38 \%$, and 18-35\% for latewood) at the ShB_500S, ShB_900S, and ShB_900N sites, respectively. Other statistics of standard chronologies do not have very high values. However, during period of instrumental climatic observations EPS is above the threshold of 0.85 and SNR is sufficient for using chronologies in dendroclimatic analysis. LWW has the largest standard deviation and sensitivity coefficient and the lowest autocorrelation values among the width variables.

Within-site correlations (Online Resource, Table S1) show that total ring width has more contribution from earlywood ( $r=0.82-0.94)$ than from latewood $(0.66-0.84)$, whereas the widths of 
these two zones have much less similarity between themselves (0.17-0.63). LWR has high correlations with LWW (0.65-0.77) and weak negative relationships with EWW (from -0.44 to 0.02). Between-site correlation analysis (Online Resource, Table S2) demonstrates that relationships between chronologies are closer on the same slope at different elevations (0.54-0.72) than at one elevation on opposite slopes (0.33-0.59). Differences in both slope aspect and elevation lead to the lowest correlation coefficients $(0.17-0.23)$ between chronologies of width variables; however, latewood ratio chronologies remain positively correlated (0.54).

Climatic influence during the current warm season on pine growth is shown in Fig. 3. It is evident that climatic responses in EWW and LWW are separate and that TRW contains a weakened combination of both responses with the dominance of EWW. Correlations between LWR and climatic factors also show the distinctive impact of environment.

In the bottom part of the southern slope, earlywood growth positively reacts to precipitation from the beginning of April to the beginning of June; its positive response from the end of June to the first half of July is insignificant. Latewood growth is also stimulated by precipitation, for the most part in July-August. As a result, total ring width positively responds to precipitation both in spring and in the first half of July. Increase of elevation leads to the weakening of EWW and TRW reaction to the precipitation in spring; however, the responses of both latewood width and ratio are only shifted to the earlier dates by $\sim 10-15$ days. On the other hand, pine growing on the northern slope is almost independent from precipitation. The only significant reaction is the decrease of the latewood ratio by precipitation in April.

Reactions of pine growth to the warm season temperatures are negative on the southern slope. In earlywood, it starts from the beginning and third decade of May at the bottom and top of the slope, respectively, and ends at approximately the summer solstice. Latewood growth is restricted by temperatures in the second and third decades of August at both sites, with stronger reaction at the top. TRW registers mostly a negative influence of early spring temperatures. Regarding ring structure, the latewood ratio on the southern slope has a positive relationship with May-July temperatures at both elevations. A negative reaction to warmth in the second and third decades of August is significant only on the top of the slope. For the northern slope, temperature impact is less significant. The most prominent positive relationship is observed between LWW and temperature from the end of July to the beginning of August, with similar but weaker reaction of LWR. Additionally, LWR has slightly positive correlations with temperatures from May to the beginning of June.

The comparison of pine growth reaction to the warm season climatic conditions over two subperiods (1951-1990 and 1976-2015) showed some notable shifts in climate-growth relationships, both for earlywood and latewood (Online Resource, Fig. S6). Maximal response of EWW and TRW to precipitation moved to the earlier dates (from mid-July to the end of June) and became stronger at 
all three sites; their response to temperature strengthened slightly in the second half of May at the bottom of the southern slope. In regards to latewood width, its response to May-July temperatures became less positive for both slopes; correlations between LWR and both climatic factors shifted to more negative values in this part of the season. Closer to the end of the ring development, a shift in timing to later dates occurred in the climatic influence on LWW and LWT ( $\sim 5$ days for temperatures, 10-20 days for precipitation).

\section{Discussion}

Scots pine is an evergreen conifer, and is thus expected to have photosynthesis in needles formed during previous years in early spring at $2-3^{\circ} \mathrm{C}$ above zero (cf. Suvorova et al. 2005, 2011). The beginning of cambial activity is expected when average daily air temperature reaches the threshold of 5-9 ${ }^{\circ} \mathrm{C}$ (Rossi et al. 2007, 2009; Kraus et al. 2016); at the sampling sites this threshold is observed usually after snowmelt even on the northern slope (Fig. 1b). The ending of tracheid differentiation probably occurs at a similar temperature threshold at the end of the season (Rossi et al. 2008). Therefore, we considered the period of average daily air temperatures above $5^{\circ} \mathrm{C}$ as the pine vegetative season with its widest boundaries (without possible input of other factors such as spring droughts or snowmelt timing in the case of an unusually heavy snowpack; e.g., Vaganov et al. 1999; Ren et al. 2015, 2018).

It has not yet been defined which of the two factors of heat supply more limits tree growth in mountains, the duration of the vegetative season (dates of its beginning and termination) or temperatures during its first half (Bouriaud et al. 2005; King et al. 2013b; Jochner et al. 2018). However, both of these factors undoubtedly depend on the elevational temperature gradient. On the other hand, although in the study area the amount of precipitation generally increases with elevation, this effect is the most noticeable at scales from $5-10 \mathrm{~km}$ due to advection and other physical mechanisms (e.g., Daly et al. 2017). Another factor making estimation of precipitation at fine spatiotemporal scales more difficult is its stochastic distribution (Krajewski et al. 2003; Buytaert et al. 2006). Therefore, the large distance between available weather stations and the absence of direct instrumental observations does not allow for quantitative estimation of precipitation differences between sampling sites. Nonetheless, indirect assessment of moisture availability in general on the sampling sites is possible. Vegetation cover is similar on both sites of the southern slope, including the undercover and grass, which indicates the similarity of environments (sf. Dorji et al. 2014; Gao et al. 2017); the presence of more drought-sensitive species (e.g. Abies sibirica, Rubus idaeus and Ribes rubrum) and the absence of the more xeric Spiraea media and Caragana arborescens on the northern slope indicates a higher moisture supply there than on the southern slope (cf. Nazimova and Polikarpov 1996; Chytry et al. 2008; Kharuk et al. 2013). Therefore, the main elevational gradients of microclimate in the study area are the vegetative season timing and air temperatures. In contrast, the 
most substantial differences between adjacent opposite slopes are in received direct solar radiation (Fig. 1c). Its consequences are lower surface temperatures and lower potential evapotranspiration (King et al. 2015) on the shadowed northern slope than on the sunlit southern slope (because sunlit surfaces can overheat by up to $10^{\circ} \mathrm{C}$; Ermida et al. 2014), despite possible similarities of precipitation and air temperatures (cf. King et al. 2013a; Daly et al. 2017; but Krajewski et al. 2003; Strachan and Daly 2017).

The actual influence of these distinctions on microclimate and tree growth depends on the amount of available moisture. If received moisture is sufficient, the actual evapotranspiration corresponds to the potential evapotranspiration. Plants at that point have sufficient resources to increase the speed of photosynthesis, which leads to the higher concentration of carbohydrates and growth hormones and thus to the stimulation of growth processes on the southern slope. If soil moisture is insufficient, the soil dries up, plants begin to suffer from water stress, and transpiration speed decreases. On the other hand, the temperature of foliage without cooling by transpiration can increase up to the point of heat stress, despite moderate air temperatures (Jackson et al. 1981). These negative effects reduce the speed of photosynthesis and slow down growth. In comparison, one should expect slower but more stable tree growth on the shadowed northern slope due to a lesser water deficit and lower temperatures of tree tissues.

The landscape-driven distinctions of a microclimate are reflected in the characteristics of tree growth. The ratio of growth rates (mean values of tree ring width) between sites of the southern slope reflects a temperature gradient (Vaganov et al. 1996; Di Filippo et al. 2015; Körner 2016). Since trees on a northern slope have significantly slower growth, it is possible to draw a conclusion about the regulation of tree growth rate mainly by the direct influence of solar radiation and the surface temperature, and it also indicates the relatively low impact of a moisture deficit, which is typical for the middle of a growth range. In general, patterns in the growth rate and age of trees correspond to other observations in mountain ecosystems (King et al. 2013a; Babushkina et al. 2018).

The latewood ratio as a tree growth variable has interesting variability patterns. This variable is rather stable for each individual tree because interrelations of EWW and LWW with TRW are close to linear functions (Fig. 2c). Significant differences of mean LWR between trees within one site can be caused both by microconditions for an individual tree, and by the genetically caused internal patterns of tree ring formation (cf. Darikova et al. 2013 for distinction of the anatomical structure in the scion and rootstock of heterografts, forming under identical external conditions). However, differences in conditions between sites are much more drastic compared with within-site microconditions variation, although they do not cause further variation of LWR values. On the other hand, as shown in the work of King et al. (2013a), the genetic composition of a tree population has no elevational gradients or dependence on slope orientation. Therefore, individual trees have different genotypes, but stands are 
of the same genetic composition on all three sites. This similarity in patterns of variability support the assumption that the average ratio of earlywood and latewood in a ring is primarily defined by a tree genotype, probably via regulation of the transition process between them (Fukatsu and Nakada 2018). However, its deviations from the mean value still contain information on environmental conditions during the specific season.

Low values of standard deviations and coefficients of sensitivity for all variables of pine growth in the study area are also typical for habitats in the middle of the distribution range where climatic fluctuations do not approach boundaries of species tolerance during the majority of seasons, and tree growth is complacent. Similar statistics were earlier noted in the study area for Siberian spruce (Babushkina et al. 2018). Higher sensitivity and low autocorrelation of LWW are caused by its lesser dependence on the previous season conditions in comparison with EWW (Oberhuber et al. 1998; Lebourgeois 2000, 2007).

Both between-site correlations and dendroclimatic analysis show that the elevational gradient influences the strength and seasonality of climatic response but the slope orientation modulates it more significantly. On the southern slope, tree growth has a positive response to precipitation and a negative one to temperature, typical for moderate moisture limitation (Fig. 3; cf. Babushkina and Belokopytova 2014). The timing of this response is completely divided in earlywood and latewood, which indicates the key periods during their formation. The shift of this timing with elevation corresponds to a difference in the vegetative season duration due to temperature lapse. On the northern slope, loss of moisture at the expense of transpiration is much lower; therefore, significant correlations between growth variables and climatic factors are practically absent for the entire period of observations, except for the stimulation of growth of latewood by temperatures. It is interesting that LWR is positively correlated with the temperatures of May-June and negatively reacts to August temperature at all three sites. On the southern slope it is connected with the limitation of growth by moisture deficit (because of its coupling with the positive reaction to July-August precipitation). However, the presence of the temperature response on the northern slope can also be caused by other factors; for example, Carteni et al. (2018) assumed that the earlywood-to-latewood transition under sufficient water supply is regulated by the availability of carbohydrates, that is, indirectly by temperature via the rate of transpiration and photosynthesis processes.

In the region, a significant trend of temperature increase is observed during the entire year. Acceleration of this process after construction of the Sayano-Shushenskoe Reservoir (Babushkina et al. 2018) makes the study area especially interesting because it allows prediction of forest reactions to further warming in the rest of the region. In terms of the environmental consequences of climate change, warming yielded an increase in the duration of the vegetative season and in heat supply. Combining this factor with a constant amount of precipitation observed in the study area led to a 
decrease in the water availability for plants and the possibility of an increase in drought frequency and intensity in moisture-limited habitats (Tchebakova et al. 2011; IPCC 2013; Cook et al. 2014; Zhang et al. 2016). Indeed, the maxima of climatic reactions shifted at all sites, which showed the binding of their seasonality to the local climatic trends. On the southern slope, moisture limitation became more pronounced both in earlywood and in latewood. On the northern slope, earlywood in the course of warming also began to register signs of a moisture deficit. However, the climatic reaction of latewood (developing during the period of maximum precipitation) remained stable and closer to temperaturelimited habitats. However, these shifts of sensitivity may not only be attributed to climatic trends alone, but also to other long-term changes accompanying it, such as the maturation of forest stands leading to the increased climate sensitivity of radial growth (e.g., Schuster and Oberhuber 2013), competition, and changes of microclimate due to feedbacks from transpiration and snowpack evolution, among other factors. These concerns may be addressed in future research, e.g., by comparison of the considered sites with forest stands of similar structure and landscape position but located far from the reservoir. Moreover, detailed investigation of microclimate (daily dynamics of air and various surface temperatures, soil moisture at different depths and so forth) performed directly at the sampling sites may be beneficial to a deeper understanding of the mechanisms of its formation and relationships with tree growth in the study area.

\section{Conclusions}

The performed research revealed the following patterns of Scots pine growth in relatively comfortable environmental conditions between its growth range boundaries:

1. The growth rate of trees in the study area depends on the local microclimate, including temperatures and solar radiation. At the same time, the proportion of earlywood and latewood seems to depend more on the genotype of individual trees within population than on local growth conditions. Joint research with geneticists may help prove this hypothesis.

2. EWW and LWW as separate indicators of growth have temporally separate climatic responses, which are stronger in comparison to TRW. The deviation of LWR from its mean value also contains indirect information about climatic conditions.

3. The seasonality of the climatic response of tree growth is regulated by dates of air temperature meeting xylogenesis' threshold in spring and autumn, determined by the elevational lapse of temperature. Slope orientation significantly modulates solar radiation (the difference between considered opposite slopes varies during the year from 17 to 68\%) and thus changes surface temperatures and potential evapotranspiration. As a result, slope orientation plays the main role in the definition of the direction of this response: moisture-limited on the southern slope and mixed on the northern slope. 
4. Climate change in the recent decades led to a shift of seasonality of climatic reactions regardless of landscape. On the moisture-limited southern slope, strengthening of this climatic response was observed. On the northern slope, long-term change of climatic response diverged in earlywood and latewood, probably due to greater moisture supply during the second half of the vegetative season.

\section{Acknowledgements}

The authors thank employees of the National Park 'Shushensky Bor' and personally its director Tolmachev V.A. for providing permission and facilitating fieldwork in the park territory. We also appreciate Dr. Korets M.A. (Sukachev Institute of Forest, Krasnoyarsk, Russia) for their provided calculation of daily solar radiation at the sampling sites. The research was supported by the Russian Foundation for Basic Research (17-04-00315, 17-44-240809).

\section{References}

Alisov BP (1956) Climate of the USSR. Moscow State University, Moscow 128 p [In Russian]

Anderson RG, Goulden ML (2011) Relationships between climate, vegetation, and energy exchange across a mountain gradient. J Geophys Res Biogeosci 116(G01026). https://doi.org/10.1029/2010JG001476

Babushkina EA, Belokopytova LV (2014) Climatic signal in radial increment of conifers in forest steppe of Southern Siberia and its dependence on local growing conditions. Russ J Ecol 45(5):325-332. https://doi.org/10.1134/S1067413614050038

Babushkina E., Belokopytova L., Zhirnova D., Barabantsova A., Vaganov E. (2018) Divergent growth trends and climatic response of Picea obovata along elevational gradient in Western Sayan mountains, Siberia. J Mt Sci 15(11):2378-2397. https://doi.org/10.1007/s11629-018-4974-6

Balducci L, Cuny H, Rathgeber C, Deslauriers A, Giovannelli A, Rossi S (2016) Compensatory mechanisms mitigate the effect of warming and drought on wood formation. Plant Cell Environ 39:1338-1352. https://doi.org/10.1111/pce.12689

Barber VA, Juday GP, Finney BP (2000) Reduced growth of Alaskan white spruce in the twentieth century from temperature-induced drought stress. Nat 405(6787):668.

Barry RG (1992) Mountain Weather and Climate. Routledge Physical Environment Series, London, Routledge, $2^{\text {nd }}$ ed., $402 \mathrm{p}$

Bauerle WL, Oren R, Way DA, Qian SS, Stoy PC, Thornton PE, Bowden JD, Hoffman FM, Reynolds RF (2012) Photoperiodic regulation of the seasonal pattern of photosynthetic capacity and the implications for carbon cycling. Proc Natl Acad Sci 109(22):8612-8617. https://doi.org/10.1073/pnas.1119131109 
Becker A, Bugmann H (eds) (2001) Global change and mountain regions. IGBP Report 49, Royal Swedish Academy of Sciences, Stockholm, 48 p

Bouriaud O, Leban JM, Bert D, Deleuze C (2005) Intra-annual variations in climate influence growth and wood density of Norway spruce. Tree Physiol 25:651-660. https://doi.org/10.1093/treephys/25.6.651

Buffo J, Fritschen LJ, Murphy JL (1972) Direct solar radiation on various slopes from 0 to 60 degrees north latitude. Res. Pap. PNW-RP-142. Portland, OR: US Department of Agriculture, Forest Service, Pacific Northwest Research Station. 75 p, 142.

Buytaert W, Celleri R, Willems P, De Bievre B, Wyseure G (2006) Spatial and temporal rainfall variability in mountainous areas: A case study from the south Ecuadorian Andes. J Hydrol 329(3-4):413-421. https://doi.org/10.1016/j.jhydrol.2006.02.031

Cai Q, Liu Y (2013) Climatic response of three tree species growing at different elevations in the Luliang Mountains of Northern China. Dendrochronol 31:311-317. https://doi.org/10.1016/j.dendro.2012.07.003

Carteni F, Deslauriers A, Rossi S, Morin H, De Micco V, Mazzoleni S, Giannino F (2018) The physiological mechanisms behind the earlywood-to-latewood transition: A process-based modeling approach. Front Plant Sci 9:1053. https://dx.doi.org/10.3389/fpls.2018.01053

Chen J, Saunders SC, Crow TR, Naiman RJ, Brosofske KD, Mroz GD, Brookshire BL, Franklin JF (1999) Microclimate in forest ecosystem and landscape ecology: variations in local climate can be used to monitor and compare the effects of different management regimes. BioSci 49(4):288-297. https://doi.org/10.2307/1313612

Chytrý M, Danihelka J, Kubešová S, Lustyk P, Ermakov N, Hájek M, Hájková P, Kočí M, Otýpková Z, Roleček J, Řezníčková M, Šmarda P, Valachovič M, Popov D, Pišút I (2008) Diversity of forest vegetation across a strong gradient of climatic continentality: Western Sayan Mountains, southern Siberia. Plant Ecol 196(1):61-83. https://doi.org/10.1007/s11258-007-9335-4

Cook ER (1985) A time series analysis approach to tree ring standardization. Dissertation, University of Arizona, Tucson, p 171

Cook ER, Kairiukstis LA (eds) (1990) Methods of dendrochronology. Kluwer, Dordrecht 394 $\mathrm{p}$

Cook ER, Krusic PJ (2005) Program ARSTAN: a tree-ring standardization program based on detrending and autoregressive time series modeling, with interactive graphics. Lamont-Doherty Earth Observatory, Columbia University, Palisades

Cook BI, Smerdon JE, Seager R, Coats S (2014) Global warming and 21st century drying. Clim Dyn 43(9-10):2607-2627. https://doi.org/10.1007/s00382-014-2075-y 
Cooke JE, Eriksson ME, Junttila O (2012) The dynamic nature of bud dormancy in trees: environmental control and molecular mechanisms. Plant Cell Environ 35(10), 17071728. https://doi.org/10.1111/j.1365-3040.2012.02552.x

Daly C, Slater ME, Roberti JA, Laseter SH, Swift Jr LW (2017) High- resolution precipitation mapping in a mountainous watershed: ground truth for evaluating uncertainty in a national precipitation dataset. International Journal of Climatology 37:124-137. https://doi.org/10.1002/joc.4986

Darikova YA, Vaganov EA, Kuznetsova GV, Grachev AM (2013) Changes in the anatomical structure of tree rings of the rootstock and scion in the heterografts of Siberian pine. Trees 27(6):16211631. https://doi.org/10.1007/s00468-013-0909-6

Deng SF, Yang TB, Zeng B, Zhu X.F, Xu HJ (2013) Vegetation cover variation in the Qilian Mountains and its response to climate change in 2000-2011. J Mt Sci 10(6):1050-1062. https://doi.org/10.1007/s11629-013-2558-z

Di Filippo A, Pederson N, Baliva M, Brunetti M, Dinella A, Kitamura K, Knapp HD, Schirone B, Piovesan G (2015) The longevity of broadleaf deciduous trees in Northern Hemisphere temperate forests: insights from tree-ring series. Front Ecol Evol 3:46. https://doi.org/10.3389/fevo.2015.00046

Dorji T, Moe SR, Klein JA, Totland Ø (2014) Plant species richness, evenness, and composition along environmental gradients in an alpine meadow grazing ecosystem in central Tibet, China. Arct Antarct Alp Res 46(2):308-326, https://doi.org/10.1657/1938-4246-46.2.308

Drew DM, Downes GM (2015) A model of stem growth and wood formation in Pinus radiata. Trees 29:1395-1413. https://doi.org/10.1007/s00468-015-1216-1

Ermida SL, Trigo IF, DaCamara CC, Göttsche FM, Olesen FS, Hulley G (2014) Validation of remotely sensed surface temperature over an oak woodland landscape - The problem of viewing and illumination geometries. Remote Sens Environ 148:16-27. https://doi.org/10.1016/j.rse.2014.03.016

Fritts HC (1976) Tree rings and climate. Academic Press, London

Fukatsu E, Nakada R (2018) The timing of latewood formation determines the genetic variation of wood density in Larix kaempferi. Trees 32(5):1233-1245. https://doi.org/10.1007/s00468018-1705-0

Gao N, Zhou J, Zhang X, Cai W, Guan T, Jiang L, Du H, Yang D, Cong Z, Zheng Y (2017) Correlation between vegetation and environment at different levels in an arid, mountainous region of China. Ecol Evol 7(14):5482-5492. https://doi.org/10.1002/ece3.3088

Gyllenstrand N, Clapham D, Källman T., Lagercrantz U (2007) A Norway spruce FLOWERING LOCUS $\mathrm{T}$ homolog is implicated in control of growth rhythm in conifers. Plant Physiol 144:248-257. https://doi.org/10.1104/pp.107.095802 
Holmes RL (1983) Computer-assisted quality control in tree-ring dating and measurement. Tree-Ring Bull 43:68-78.

Huang S, Rich PM, Crabtree RL, Potte, CS, Fu P (2008) Modeling monthly near-surface air temperature from solar radiation and lapse rate: Application over complex terrain in Yellowstone National Park. Phys Geogr 29(2):158-178. https://doi.org/10.2747/0272-3646.29.2.158.

Jackson RD, Idso SB, Reginato RJ, Pinter PJ (1981) Canopy temperature as a crop water stress indicator. Water Resour Res 17(4):1133-1138.

Jochner M, Bugmann H, Nötzli M, Bigler C (2018) Tree growth responses to changing temperatures across space and time: a fine-scale analysis at the treeline in the Swiss Alps. Trees 32(2):645-660. https://doi.org/10.1007/s00468-017-1648-X

IPCC (2013) Climate Change 2013: The Physical Science Basis, Contribution of Working Group I to the Fifth Assessment Report of the Intergovernmental Panel on Climate Change, Cambridge Univ. Press, Cambridge, U. K.

Karlsson E, Pomade L (2013) Methods of estimating potential and actual evaporation. Salt Lake City: Department of Water Resources Engineering $11 \mathrm{p}$

Kelsey KC, Redmond MD, Barger NN, Neff JC (2018) Species, climate and landscape physiography drive variable growth trends in subalpine forests. Ecosyst 21(1):125-140. https://doi.org/10.1007/s10021-017-0139-7

Kharuk VI, Im ST, Petrov IA, Dvinskaya ML, Fedotova EV, Ranson KJ (2017) Fir decline and mortality in the southern Siberian Mountains. Reg Environ Chang 17(3):803-812. https://doi.org/10.1007/s10113-016-1073-5

King GM, Gugerli F, Fonti P, Frank DC (2013a) Tree growth response along an elevational gradient: climate or genetics? Oecol 173(4):1587-1600. https://doi.org/10.1007/s00442-013-2696-6

King G, Fonti P, Nievergelt D, Büntgen U, Frank D (2013b) Climatic drivers of hourly to yearly tree radius variations along a 6 degrees $\mathrm{C}$ natural warming gradient. Agric For Meteorol 168:36-46. https://doi.org/10.1016/j.agrformet.2012.08.002

King, DA, Bachelet DM, Symstad AJ, Ferschweiler K, Hobbins M (2015) Estimation of potential evapotranspiration from extraterrestrial radiation, air temperature and humidity to assess future climate change effects on the vegetation of the Northern Great Plains, USA. Ecol Model 297:86-97. http://dx.doi.org/10.1016/j.ecolmodel.2014.10.037.

Kirchhefer AJ (2000) The influence of slope aspect on tree-ring growth of Pinus sylvestris L. in northern Norway and its implications for climate reconstruction. Dendrochronol 18:27-40.

Kirkham MB (2014) Principles of soil and plant water relations. 2 edition. Elsevier Academic Press 598 p 
Körner C (2009) Mountain Vegetation under Environmental Change. In: Jandl R, Borsdorf A, Miegroe, HV, Lackner R, Psenner R (eds) Global Change and Sustainable Development in Mountain Regions. Innsbruck University Press, Innsbruck, pp 25-29

Körner C (2016) Plant adaptation to cold climates. F1000Res 5 (F1000 Fac Rev):2769. https://doi.org/10.12688/f1000 research.9107.1

Kosmakov IV (2001) Thermal and ice regime in the upper and lower reaches of high-pressure hydroelectric power stations on the Yenisei. Klaretianum, Krasnoyarsk, 142 p [In Russian]

Krajewski WF, Ciach GJ, Habib E (2003) An analysis of small-scale rainfall variability in different climatic regimes. Hydrol Sci J 48(2):151-162. https://doi.org/10.1623/hysj.48.2.151.44694

Kraus C, Zang C, Menzel A (2016) Elevational response in leaf and xylem phenology reveals different prolongation of growing period of common beech and Norway spruce under warming conditions in the Bavarian Alps. Eur J For Res 135(6): 1011-1023. https://doi.org/10.1007/s10342016-0990-7

Kulagin AY, Davydychev, A.N., Zaitsev, G.A., 2006. Specific features of the growth of Siberian spruce (Picea obovata Ledeb.) at early stages of ontogeny in broadleaf-conifer forests of the Ufa plateau. Russ J Ecol 37(1):66-69. https://doi.org/10.1134/S1067413606010115

Latreille A, Davi H, Huard F, Pichot C (2017) Variability of the climate-radial growth relationship among Abies alba trees and populations along altitudinal gradients. For Ecol Manag 396:150-159. https://doi.org/10.1016/j.foreco.2017.04.012

Lebourgeois F (2007) Climatic signal in annual growth variation of silver fir (Abies alba Mill.) and spruce (Picea abies Karst.) from the French Permanent Plot Network (RENECOFOR). Ann For Sci 64(3):333-343. https://doi.org/10.1051/forest:2007010

Lebourgeois F (2000) Climatic signals in earlywood, latewood and total ring width of Corsican pine from western France. Ann For Sci 57(2):155-164. https://doi.org/10.1051/forest:2000166

Lebourgeois F, Rathgeber CB, Ulrich E (2010) Sensitivity of French temperate coniferous forests to climate variability and extreme events (Abies alba, Picea abies and Pinus sylvestris). J Veg Sci 21(2):364-376. https://doi.org/10.1111/j.1654-1103.2009.01148.x

Lyu L, Deng X, Zhang QB (2016) Elevation pattern in growth coherency on the southeastern Tibetan Plateau. PloS One 11(9):e0163201. https://doi.org/10.1371/ journal.pone.0163201

Meko DM, Baisan CH (2001) Pilot study of latewood-width of conifers as an indicator of variability of summer rainfall in the North American monsoon region. Int J Climatol 21(6):697-708. https://doi.org/10.1002/joc.646

McCutchan MH (1983) Comparing temperature and humidity on a mountain slope and in the free air nearby. Mon Weather Rev 111:836-845. https://doi.org/10.1175/15200493(1983)111<0836:CTAHOA>2.0.CO;2 
Miina J (2000) Dependence of tree-ring, earlywood and latewood indices of Scots pine and Norway spruce on climatic factors in eastern Finland. Ecol Model 132(3):259-273. https://doi.org/10.1016/S0304-3800(00)00296-9

Monnier Y, Prévosto B, Ripert C, Corbani AC, Fernandez C (2012) Forest microhabitats differentially influence seedling phenology of two co-existing Mediterranean oak species. J Veg Sci 23(2):260-270. https://doi.org/10.1111/j.1654-1103.2011.01358.x

Monserud RA, Tchebakova NM (1996) A vegetation model for the Sayan Mountains, southern Siberia. Can J For Res 26(6):1055-1068. https://doi.org/10.1139/x26-117

Montpellier EE, Soulé PT, Knapp PA, Shelly JS (2018) Divergent growth rates of alpine larch trees (Larix lyallii Parl.) in response to microenvironmental variability. Arct Antarct Alp Res 50(1):e1415626. https://doi.org/10.1080/15230430.2017.1415626

Myglan VS (2010) The Climate and Society of Siberia in the Small Ice Age. Siberian Federal University, Krasnoyarsk, 230 p [in Russian]

Nazimova DI, Polikarpov NP (1996) Forest zones of Siberia as determined by climatic zones and their possible transformation trends under global change. Silva Fenn 30(2-3):5587. https://doi.org/10.14214/sf.a9232

Oberhuber W, Stumboeck M, Kofler W (1998) Climate-tree-growth relationships of Scots pine stands (Pinus sylvestris $\quad$ L.) exposed to soil dryness. Trees 13(1):19-27. https://doi.org/10.1007/PL00009734

Oberhuber W, Kofler W (2000) Topographic influences on radial growth of Scots pine (Pinus sylvestris L.) at small spatial scales. Plant Ecol 146(2):229-238. https://doi.org/10.1023/A:1009827628125

Polikarpov NP, Nazimova DI (1963) The dark coniferous forests of the northern part of the west Siberian mountains. In: Forestry Research in the Forests of Siberia. Institute for Forests and Wood, Krasnoyarsk. Vol. 57. pp. 103-147 [In Russian]

Price MF, Byers AC, Friend DA, Kohler T, Price LW (eds) (2013) Mountain Geography: Physical and Human Dimensions. Berkeley, CA, University of California Press, $378 \mathrm{p}$

Ren P, Rossi S, Gricar J, Liang E, Cufar K, (2015) Is precipitation a trigger for the onset of xylogenesis in Juniperus przewalskii on the north-eastern Tibetan Plateau? Ann Bot 115(4):629-639. https://doi.org/10.1093/aob/mcu259

Ren P, Rossi S, Camarero JJ, Ellison AM, Liang E, Peñuelas J (2018) Critical temperature and precipitation thresholds for the onset of xylogenesis of Juniperus przewalskii in a semi-arid area of the north-eastern Tibetan Plateau. Ann Bot 121(4): 617-624. https://doi.org/10.1093/aob/mcx 188

Rinn F (2003) TSAP-Win: Time series analysis and presentation for dendrochronology and related applications: User reference. RINNTECH, Heidelberg $91 \mathrm{p}$ 
Rossi S, Deslauriers A, Anfodillo T, Carraro V (2007) Evidence of threshold temperatures for xylogenesis in conifers at high altitudes. Oecol 152(1):1-12. https://doi.org/10.1007/s00442-0060625-7

Rossi S, Deslauriers A, Griçar J, Seo JW, Rathgeber CB, Anfodillo T, Morin H, Levanic T, Oven P, Jalkanen R (2008) Critical temperatures for xylogenesis in conifers of cold climates. Glob Ecol Biogeogr 17(6):696-707. https://doi.org/10.1111/j.1466-8238.2008.00417.x

Rossi S, Rathgeber CB, Deslauriers A (2009) Comparing needle and shoot phenology with xylem development on three conifer species in Italy. Ann For Sci 66(2):206. https://doi.org/10.1051/forest/2008088

Shiyatov SG (1986) Dendrochronology of the higher timberline on the Urals. Nauka, Moskow 136 p [In Russian]

Schulze ED, Beck E, Müller-Hohenstein K (2005) Plant Ecology. Springer, Berlin, Heidelberg $702 \mathrm{p}$

Schulze ED, Mooney HA (eds) (2012) Biodiversity and Ecosystem Function. Springer Science $\&$ Business Media, Berlin, Heidelberg $525 \mathrm{p}$

Schuster R, Oberhuber W (2013) Age-dependent climate-growth relationships and regeneration of Picea abies in a drought-prone mixed-coniferous forest in the Alps. Can J For Res 43(7):609-618. https://doi.org/10.1139/cjfr-2012-0426

Strachan S, Daly C (2017) Testing the daily PRISM air temperature model on semiarid mountain slopes. J Geophys Res Atmos 122(11):5697-5715. https://doi.org/10.1002/2016JD025920

Suvorova GG, Yankova LS, Kopytova LD, Filippova AK (2005) Maximal photosynthesis intensity in Scots pine and Siberian spruce in Baikal region. Sib Ecol J 1(12):97-108. [In Russian]

Suvorova GG, Oskorbina MV, Kopytova LD, Yan'kova LS, Popova EV (2011) Seasonal changes in photosynthetic activity and chlorophylls in the Scots pine and Siberian spruce with optimal or insufficient moistening. Contemp Probl Ecol 4(6):626-633. https://doi.org/10.1134/S1995425511060105

Stepanov NV (2006) Flora of the Northeast of the Western Sayan and the Otdyh Island on the Yenisei (Krasnoyarsk city). Krasnoyarsk State University, Krasnoyarsk 122 p [In Russian]

Tchebakova NM, Rehfeldt G, Parfenova EI (2003) Redistribution of plant zones and populations of Siberian larch and Scots pine in Central Siberia with climate warming. Sib Ecol J 10(6):677-686. [In Russian]

Tchebakova, N.M., Rehfeldt, G.E., Parfenova, E.I., 2010. From vegetation zones to climatypes: effects of climate warming on Siberian ecosystems, in: Osawa et al. (Eds.), Permafrost Ecosystems: Siberian Larch Forests. Springer, Dordrecht, pp. 427-446. 
Tchebakova NM, Parfenova EI, Soja AJ (2011) Climate change and climate-induced hot spots in forest shifts in central Siberia from observed data. Reg Environ Chang 11: 817. https://doi.org/10.1007/s10113-011-0210-4

Tognetti R, Palombo C (2013) Take a tree to the limit: the stress line. Tree Physiol 33(9), 887890. https://doi.org/10.1093/treephys/tpt087

Tupitsyna NN (2016) Vegetation geography of Middle Siberia. KSPU, Krasnoyarsk, 213 p. [In Russian]

Vaganov EA, Shiyatov SG, Mazepa VS (1996) Dendroclimatic Study in Ural-Siberian Subarctic. Nauka Siberian Publishing Firm RAS, Novosibirsk 246 p [In Russian; English Abstract]

Vaganov EA, Hughes MK, Kirdyanov AV, Schweingruber FH, Silkin PP (1999) Influence of snowfall and melt timing on tree growth in subarctic Eurasia. Nat 400(6740):149. https://doi.org/10.1038/22087

Wigley TML, Briffa KR, Jones PD (1984) On the average value of correlated time series, with application in dendrochronology and hydrometeorology. J Clim Appl Meteorol 23:201-213. https://doi.org/10.1175/1520-0450(1984)023<0201:OTAVOC>2.0.CO;2

Wypych A, Ustrnul Z, Schmatz DR (2018) Long-term variability of air temperature and precipitation conditions in the Polish Carpathians. J Mt Sci 15(2):237-253. https://doi.org/10.1007/s11629-017-4374-3

Zhang W, Jiang Y, Wang M, Zhang L, Dong M (2015) Topography- and species-dependent climatic responses in radial growth of Picea meyeri and Larix principis-rupprechtii in the Luyashan Mountains of North-Central China. For 6(1):116-132. https://doi.org/10.3390/f6010116

Zhang J, Sun F, Xu J, Chen Y, Sang YF, Liu C (2016) Dependence of trends in and sensitivity of drought over China (1961-2013) on potential evaporation model. Geophysical Research Letters 43(1):206-213. https://doi.org/10.1002/2015GL067473

Zobel BJ, Jett JB (2012) Genetics of wood production. Springer, Berlin, Heidelberg, 337 p.

Table 1 Statistic characteristics of Pinus sylvestris site chronologies

\begin{tabular}{|c|c|c|c|c|c|c|c|c|c|c|c|c|}
\hline \multirow{2}{*}{ Statistics } & \multicolumn{4}{|c|}{ ShB_500S } & \multicolumn{4}{|c|}{ ShB_900S } & \multicolumn{4}{|c|}{ ShB_900N } \\
\hline & TRW & EWW & LWW & LWR & TRW & EWW & LWW & LWR & TRW & EWW & LWW & LWR \\
\hline \multicolumn{13}{|c|}{ Samples } \\
\hline number of trees / cores & \multicolumn{4}{|c|}{$17 / 26$} & \multicolumn{4}{|c|}{$20 / 36$} & \multicolumn{4}{|c|}{$12 / 23$} \\
\hline total cover period, years & \multicolumn{4}{|c|}{ 1916-2015 } & \multicolumn{4}{|c|}{$1908-2015$} & \multicolumn{4}{|c|}{$1907-2015$} \\
\hline total length, years & \multicolumn{4}{|c|}{100} & \multicolumn{4}{|c|}{108} & \multicolumn{4}{|c|}{109} \\
\hline mean value $^{\mathrm{ab}}$ & 2.41 & 1.71 & 0.71 & 0.30 & 1.98 & 1.38 & 0.60 & 0.31 & 1.51 & 1.07 & 0.43 & 0.28 \\
\hline \multicolumn{13}{|c|}{ Standard chronologies } \\
\hline standard deviation $^{\mathrm{a}}$ & 0.124 & 0.125 & 0.170 & 0.106 & 0.105 & 0.117 & 0.163 & 0.131 & 0.140 & 0.137 & 0.193 & 0.144 \\
\hline mean sensitivity $^{a}$ & 0.104 & 0.115 & 0.172 & 0.112 & 0.104 & 0.113 & 0.191 & 0.149 & 0.116 & 0.111 & 0.172 & 0.118 \\
\hline inter-serial correlation $^{\mathrm{a}}$ & 0.277 & 0.233 & 0.283 & 0.219 & 0.303 & 0.303 & 0.319 & 0.344 & 0.273 & 0.241 & 0.263 & 0.297 \\
\hline first-order autocorrelation ${ }^{a}$ & 0.407 & 0.373 & 0.209 & 0.128 & 0.257 & 0.271 & -0.029 & -0.037 & 0.539 & 0.553 & 0.377 & 0.434 \\
\hline signal-to-noise ratio $^{a}$ & 9.96 & 7.90 & 10.26 & 7.29 & 15.65 & 15.65 & 16.86 & 18.88 & 8.64 & 7.30 & 8.21 & 9.72 \\
\hline
\end{tabular}


${ }^{\text {a }}$ Statistics calculated over period of dendroclimatic analysis (1951-2015).

${ }^{b}$ mean values of width variables are in $\mathrm{mm}$, mean values of LWR are unitless. 

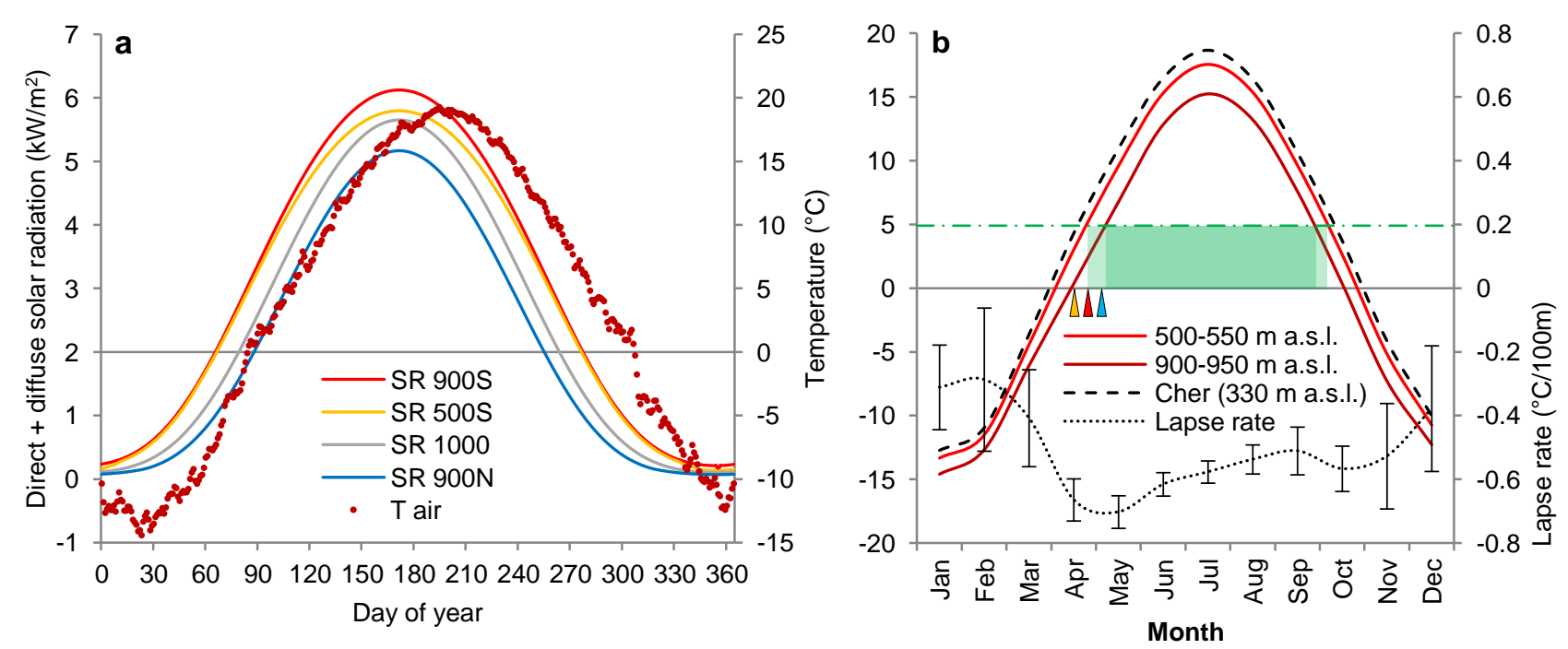

Fig. 1 Assessment of the intra-annual dynamics of air temperature and solar radiation in the study area: (a) intra-annual dynamics of the daily amount of direct + diffuse solar radiation (SR; lines) at the sampling sites and on the horizontal surface of the ridge top ( $1000 \mathrm{~m}$ a.s.l.) between sites ShB_900S and ShB_900N compared with intra-annual dynamics of daily air temperature at the Cheryomushki station (averaged for 1951-2015; dots); (b) intra-annual dynamics of air temperature at sampling site elevations (solid lines) derived from the Cheryomushki station monthly series (averaged for 1951-2015; dashed line) with monthly elevational lapse rates (mean \pm standard deviation; dotted line) estimated from comparison of temperatures at the Cheryomushki and Olenya Rechka stations before the reservoir building; average vegetative season $\left(\mathrm{T}>5^{\circ} \mathrm{C}\right.$; dash-dotted line $)$ is assessed at sampling site elevations (light and dark shades); triangles under horizontal axis mark average dates of the end of snowmelt: April 15 at ShB_500S, April 25 at ShB_900S, and May 5 at ShB_900N 

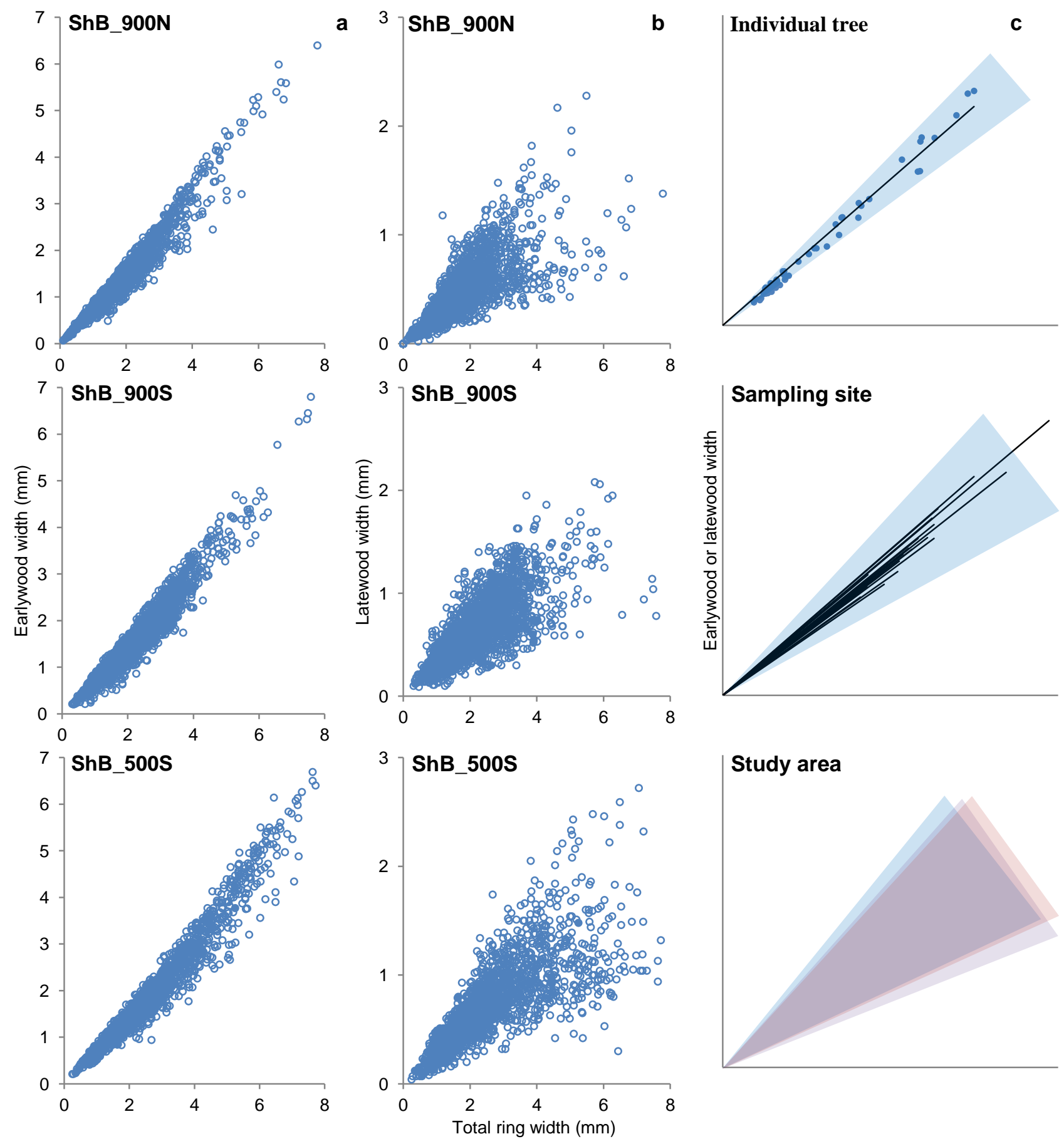

Fig. 2 Relationships between raw measurements of Pinus sylvestris earlywood width (EWW), latewood width (LWW), and total ring widths (TRW): (a) relationship between EWW and TRW at each site; (b) relationship between LWW and TRW at each site; (c) schematic ranges of earlywood ratio or latewood ratio within-tree (top), within-site (middle), and between sites within the study area (bottom). Dots represent individual tree rings, lines represent linear regressions for individual trees, and shaded areas represent $95 \%$ ranges of earlywood ratio or latewood ratio 


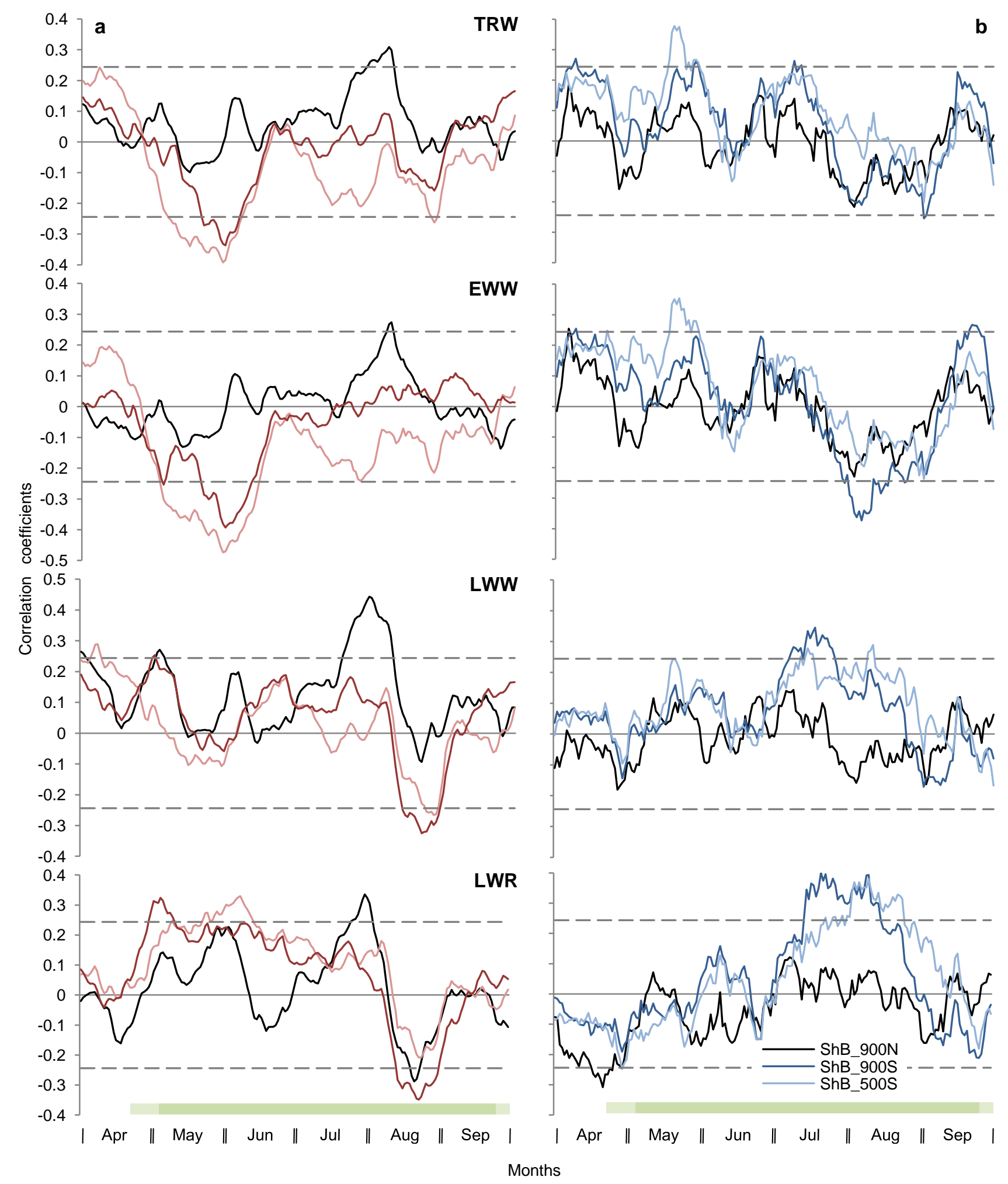

Fig. 3 Correlations between Pinus sylvestris site chronologies of TRW, EWW, LWW, and LWR with moving series (21-day window, 1-day step) of temperature (a) and precipitation (b) from April to September, derived from daily data of the Cheryomushki station for 1951-2015. Significance level $p=0.05$ is shown with thin dashed horizontal lines. Horizontal shaded bars indicate average timing of the vegetation season $\left(\mathrm{T}>5^{\circ}\right)$ at the bottom (light shade) and top of the slope (dark shade) 


\section{International Journal of Biometeorology}

\section{What prevails in climatic response of Pinus sylvestris in-between its range limits in mountains:}

\section{slope aspect or elevation?}

Dina F. Zhirnova ${ }^{1}$, Liliana V. Belokopytova ${ }^{1}$, Anna E. Barabantsova ${ }^{2}$,

Elena A. Babushkina ${ }^{1, *}$, and Eugene A. Vaganov ${ }^{3,4}$

${ }^{1}$ Khakass Technical Institute, Siberian Federal University, 27 Shchetinkina, 655017, Abakan, Russia

${ }^{2}$ National park 'Shushensky Bor', 9 Lugovaya, 662710, Shushenskoe, Russia

${ }^{3}$ Siberian Federal University, 79 Svobodny, 660041, Krasnoyarsk, Russia

${ }^{4}$ Sukachev Institute of Forest, Siberian Branch of the Russian Academy of Sciences, 50/28

Akademgorodok, 660036, Krasnoyarsk, Russia

Corresponding author: Elena A. Babushkina, <babushkina70@mail.ru>

\section{Supplementary materials}

Table S1 Correlations between Pinus sylvestris standard site chronologies of different growth variables within sites over the period of dendroclimatic analysis (1951-2015)

\begin{tabular}{|c|l|l|l|l|}
\hline \multicolumn{2}{|c|}{ Growth variables } & ShB_500S & ShB_900S & ShB_900N \\
\hline TRW & EWW & $0.920^{*}$ & $0.818^{*}$ & $0.938^{*}$ \\
\hline TRW & LWW & 0.776 & $0.661^{*}$ & $0.838^{*}$ \\
\hline TRW & LWR & 0.114 & 0.055 & $0.271^{*}$ \\
\hline EWW & LWW & $0.485^{*}$ & 0.174 & $0.625^{*}$ \\
\hline EWW & LWR & -0.244 & $-0.443^{*}$ & $0.016^{*}$ \\
\hline LWW & LWR & $0.673^{*}$ & $0.773^{*}$ & $0.647^{*}$ \\
\hline
\end{tabular}

* Significant at $p<0.05$ correlation coefficients.

Table S2 Correlations between Pinus sylvestris standard site chronologies of the same growth variables but different sites over the period of dendroclimatic analysis (1951-2015)

\begin{tabular}{|c|l|l|l|l|l|}
\hline \multicolumn{2}{|c|}{ Sites } & TRW & EWW & LWW & LWR \\
\hline ShB_500S & ShB_900S & $0.609^{*}$ & $0.544^{*}$ & $0.647^{*}$ & $0.722^{*}$ \\
\hline ShB_500S & ShB_900N & 0.165 & 0.227 & 0.207 & $0.533^{*}$ \\
\hline ShB_900S & ShB_900N & $0.371^{*}$ & $0.330^{*}$ & $0.500^{*}$ & $0.594^{*}$ \\
\hline
\end{tabular}

${ }^{*}$ Significant at $p<0.05$ correlation coefficients. 

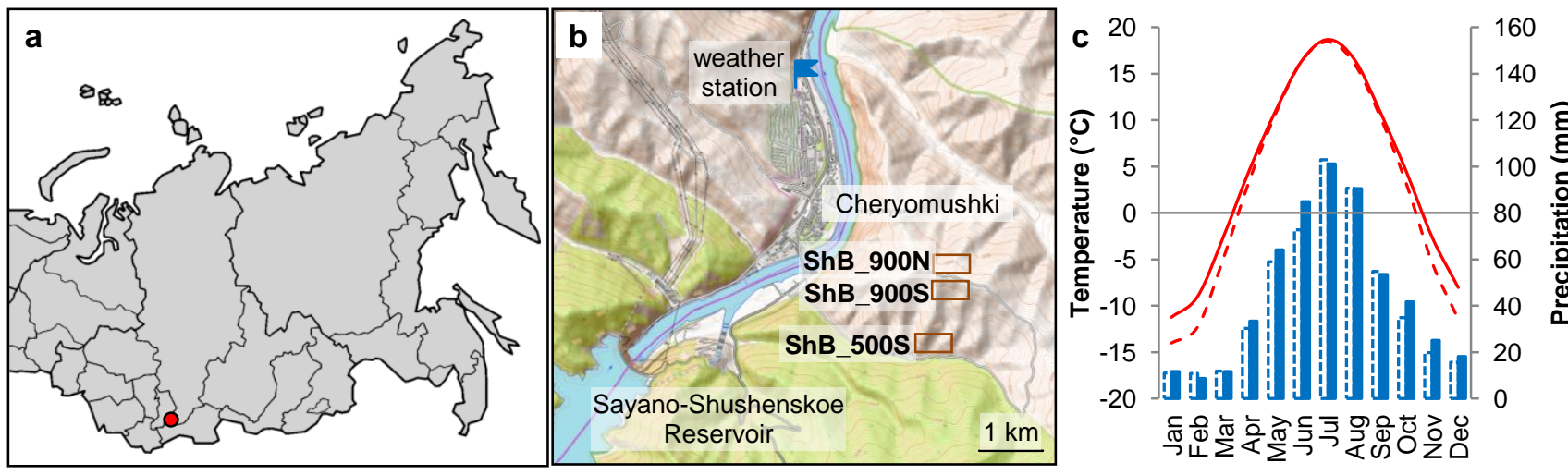

Fig. S1 The study area: (a) position of the study area in the Asian part of Russia; (b) locations of sampling sites (rectangles) and the Cheryomushki weather station (flag); (c) climatic diagram of monthly mean temperatures (lines) and amount of precipitation (bars) averaged over periods under consideration (dashed, 1951-1990; solid, 1976-2015) at the Cheryomushki weather station

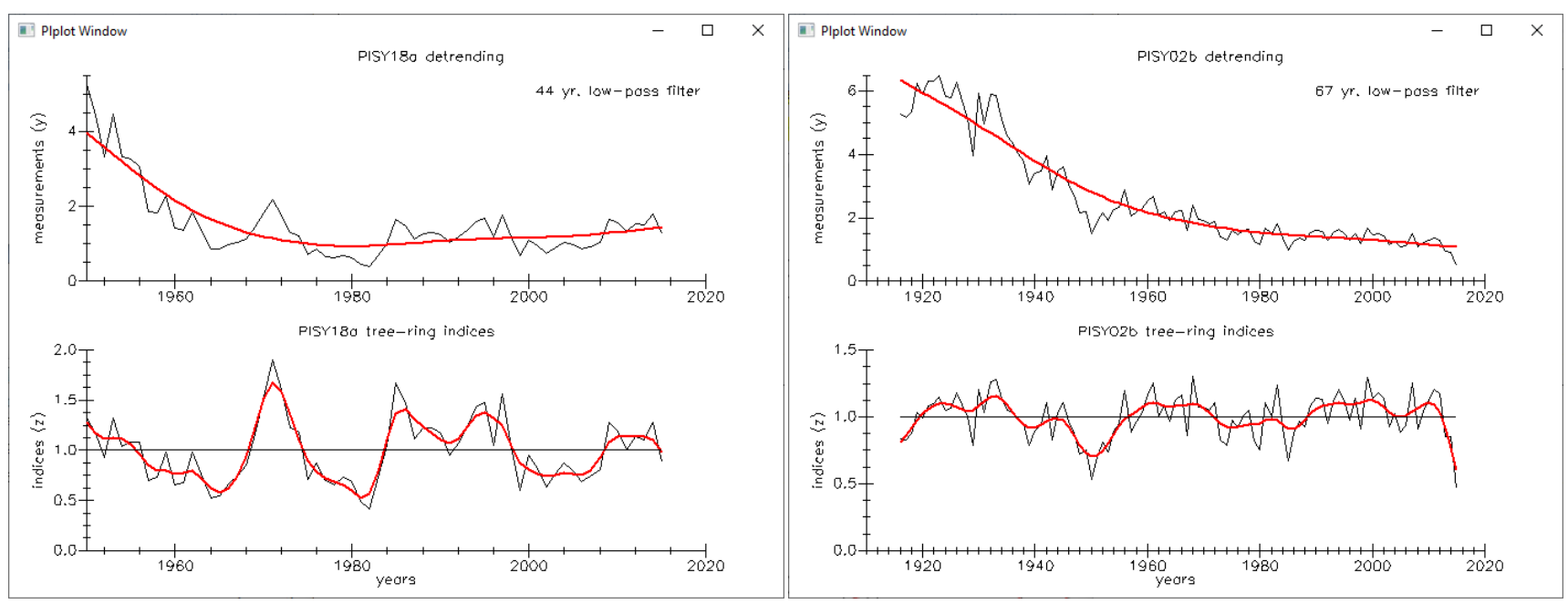

Fig. S2 Automatic standardization (detrending) of individual TRW time series in the ARSTAN program using cubic smoothing splines with a frequency response of 0.50 at $67 \%$ of the individual series length as long-term nonclimatic trends 


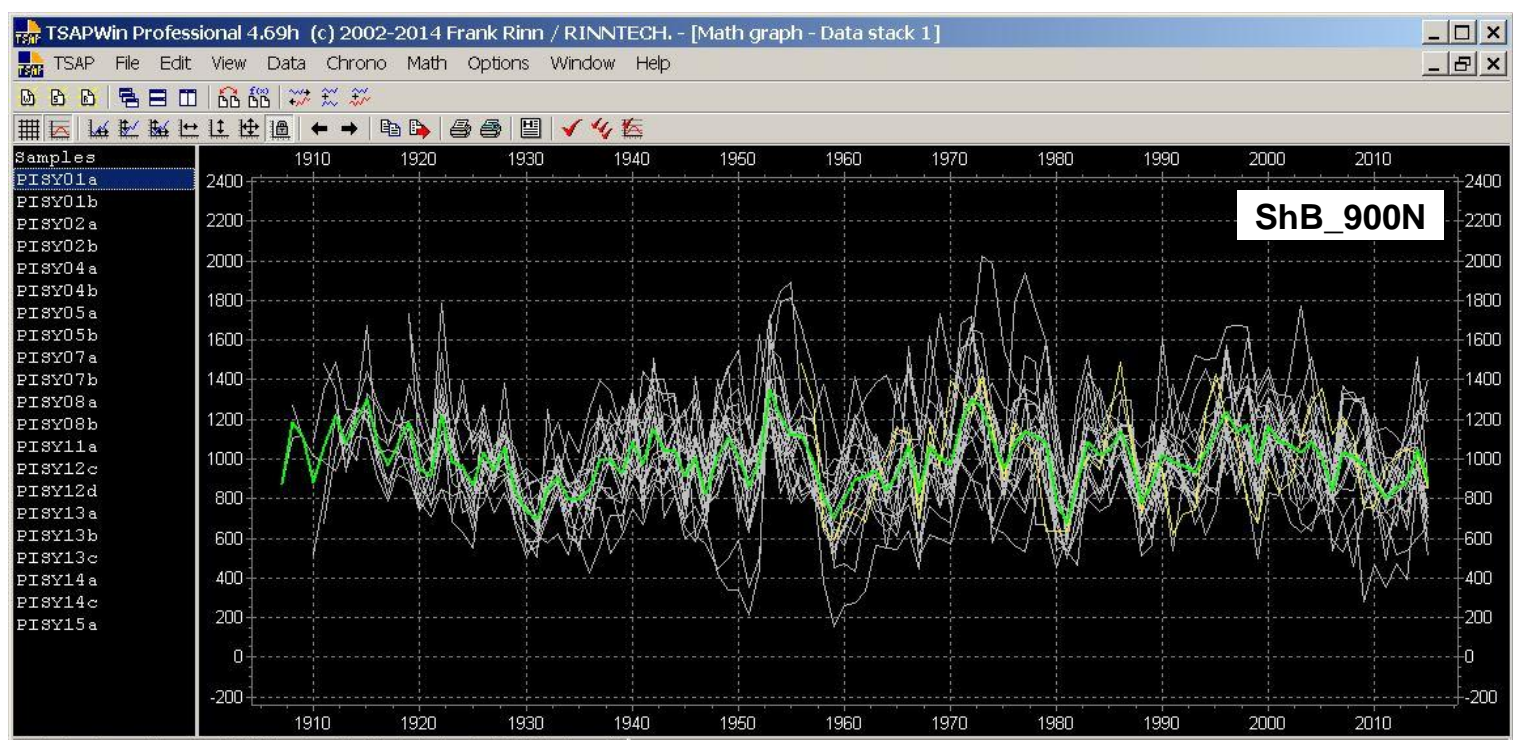

Data type:Tree Keycode:PISY01a Length:60 Date begin:1956 Date end:
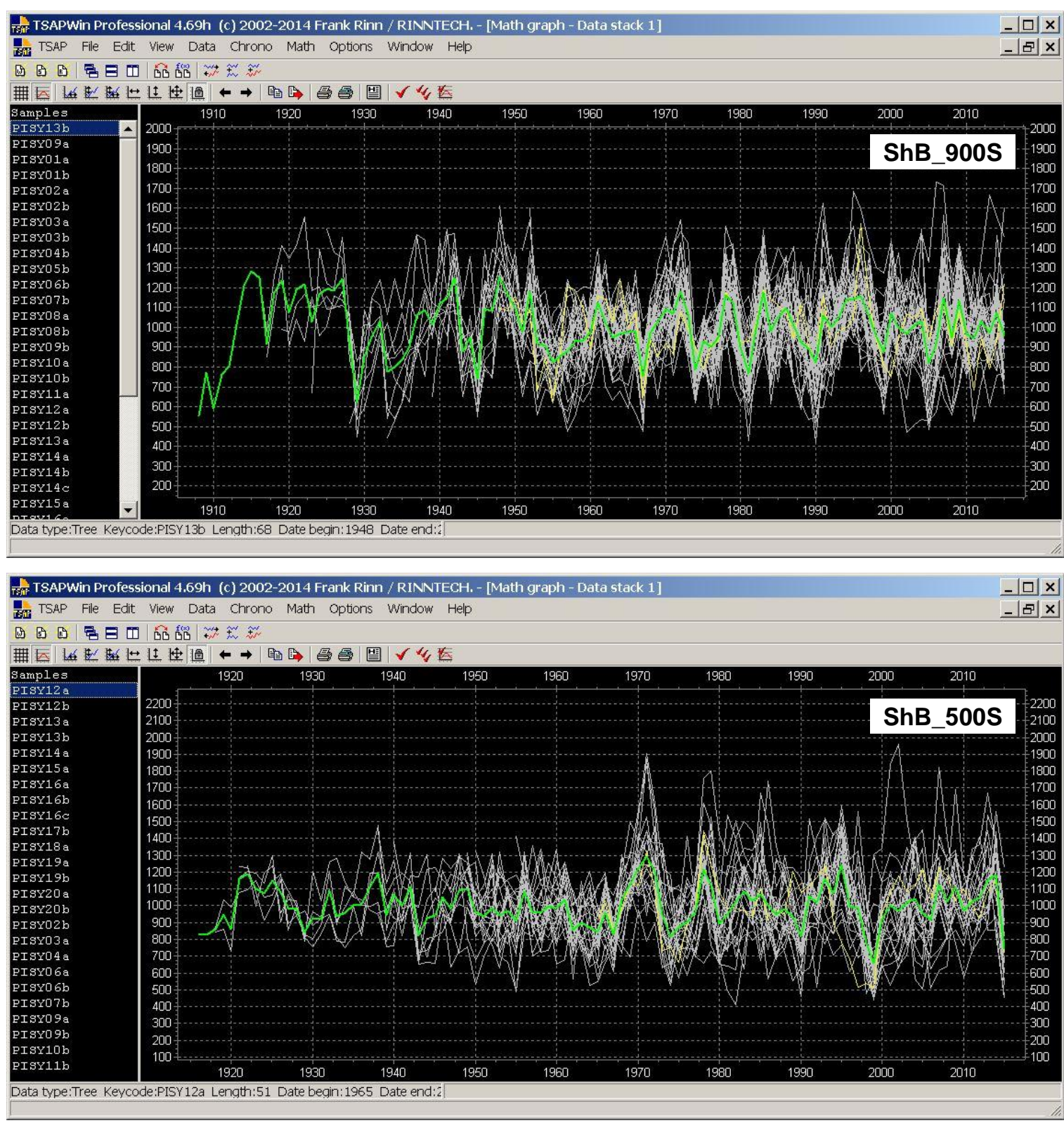

Fig. S3 Cross-dated standardized TRW individual series (white \& yellow) and site chronologies (green) in the TSAPWin program 

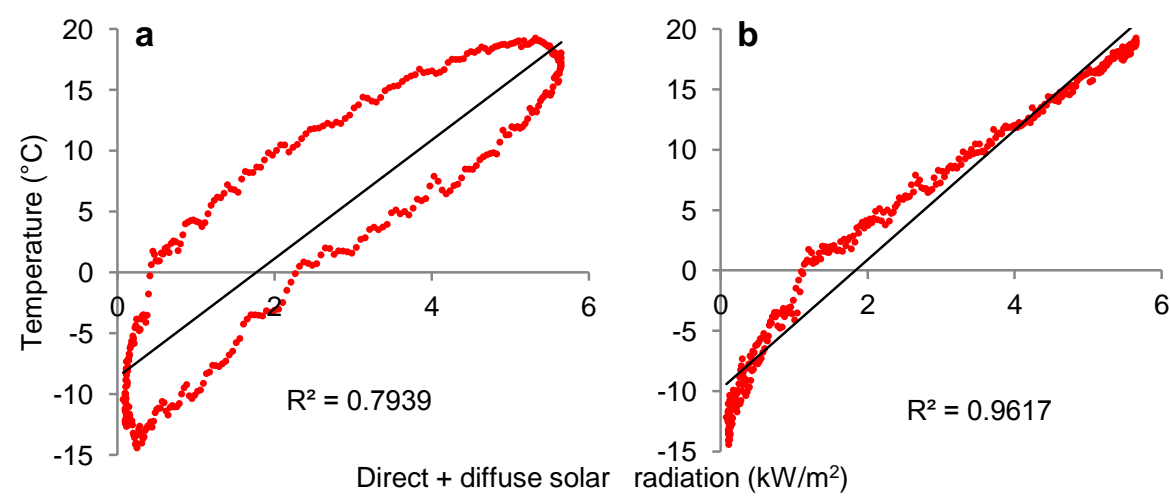

Fig. S4 Scatter plots of relationships between daily solar radiation on the horizontal surface and air temperature at the Cheryomushki station averaged for 1951-2015 (see Fig. 1a): (a) without lag; (b) with a 26-day lag of solar radiation (delay of its impact)

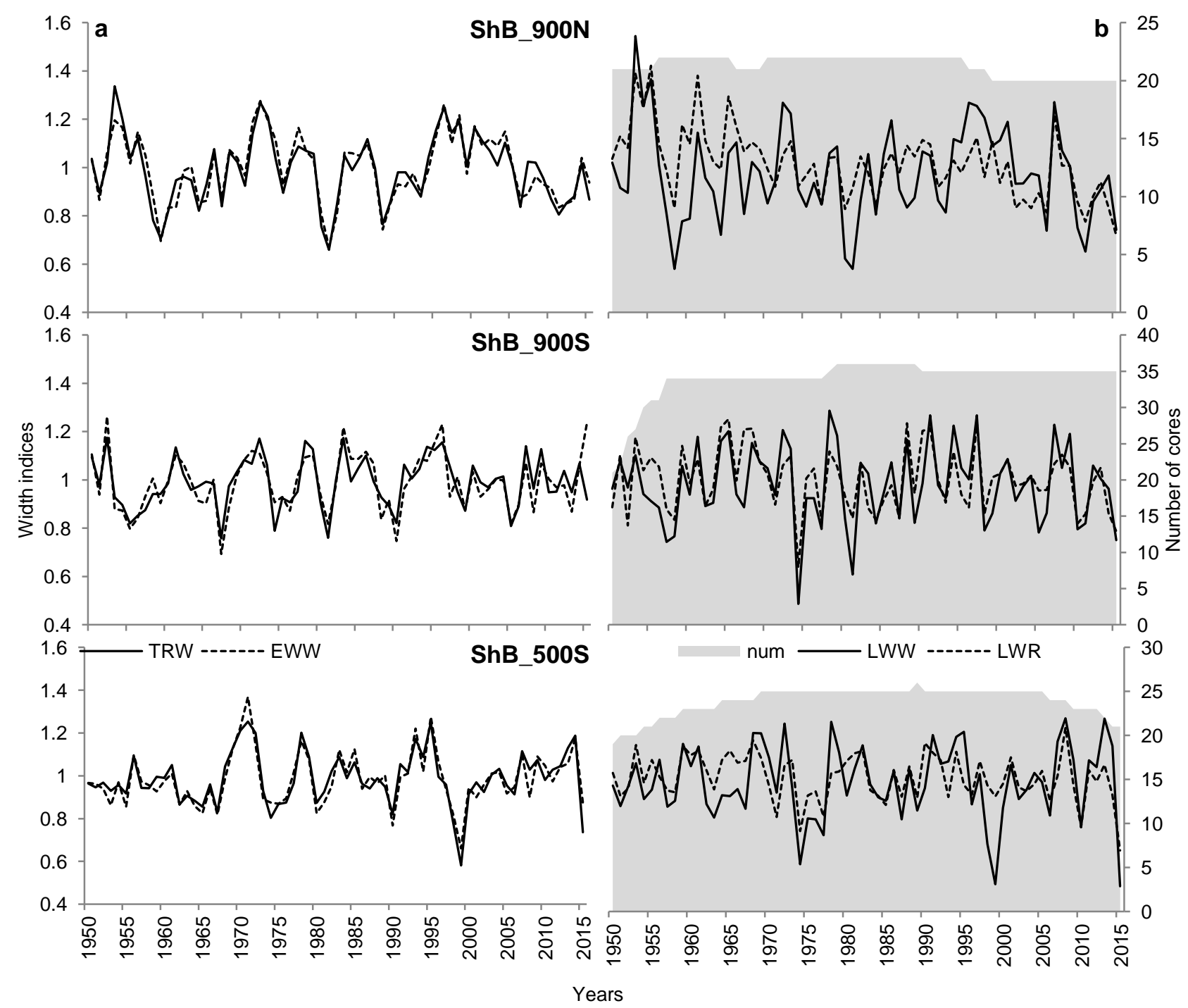

Fig. S5 Standard site chronologies of Pinus sylvestris (only 1950-2015): (a) total ring width (TRW, solid lines) and earlywood width (EWW, dashed lines); (b) latewood width (LWW, solid lines), latewood ratio (LWR, dashed lines), and sample depth (shaded areas), i.e., number of cores for each year 
ShB_900N TRW

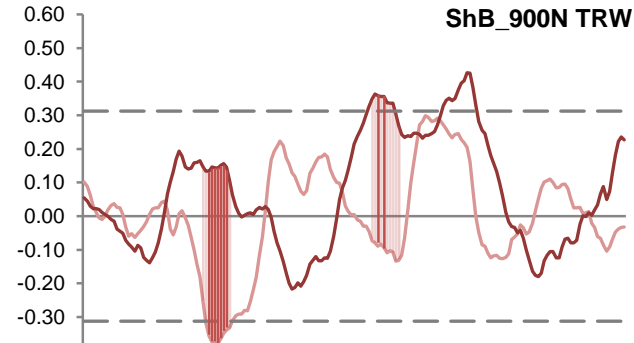

$\left.\begin{array}{l}-0.30 \\ -0.40\end{array}\right]---t[--------$

0.50

$\stackrel{\infty}{0} 0.30$

要 0.20

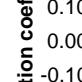

要 -0.20

0
0
-0.40
-0.50

-0.40
-0.50
0.40
0.30
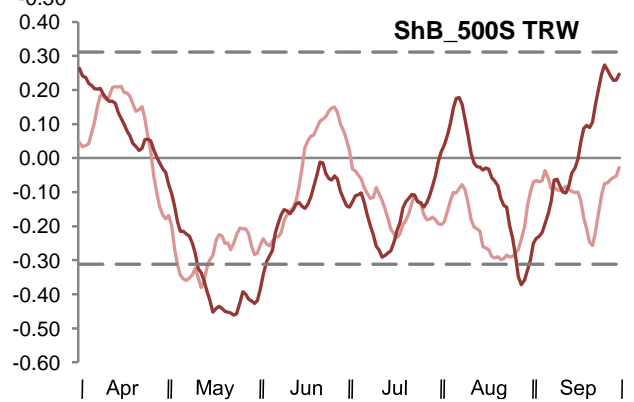

ShB_900N EWW

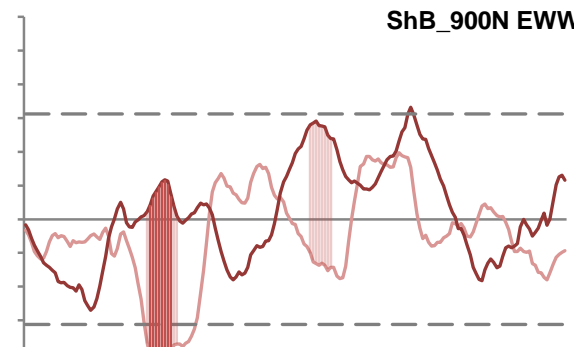

ShB_900S EWW
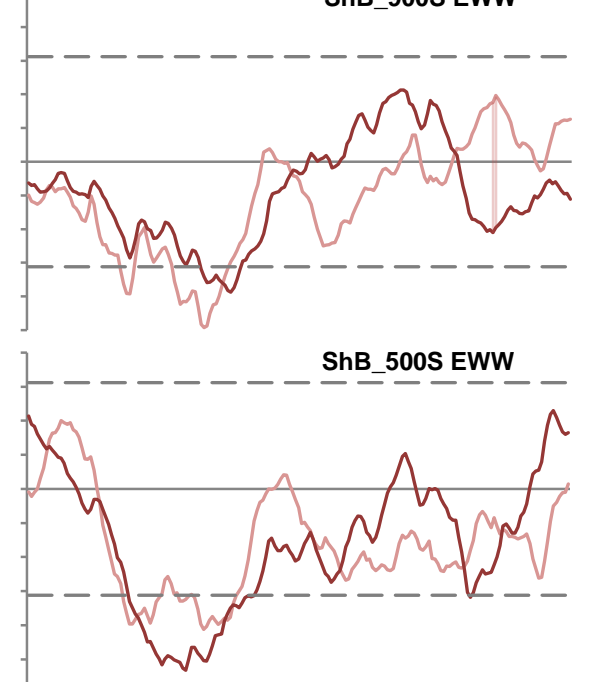

| Apr || May || Jun || Jul || Aug || Sep |

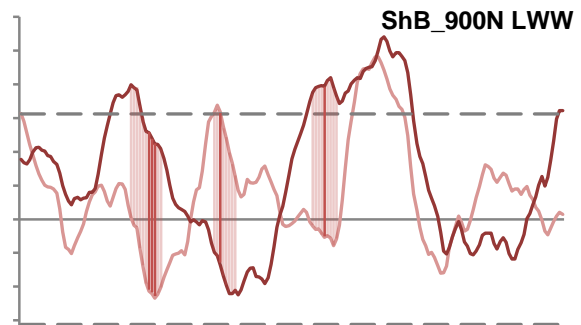

ShB 900S LWW
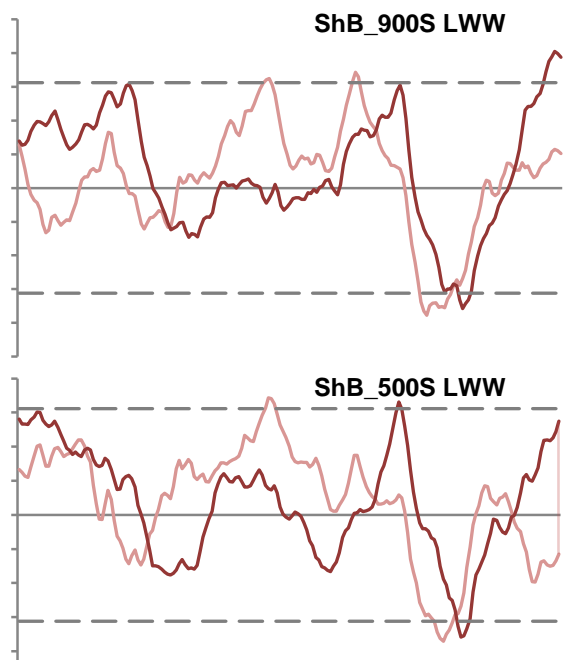

ShB 900N LWR

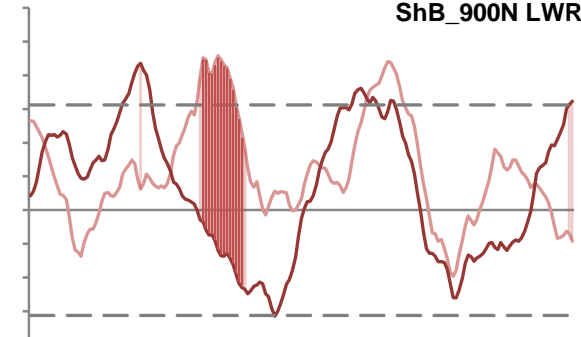

ShB 900S LWR
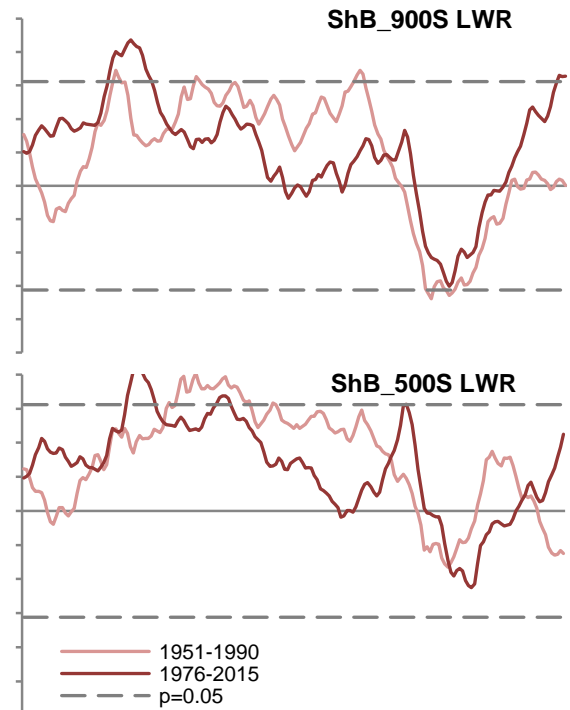

| Apr || May || Jun || Jul || Aug || Sep | 

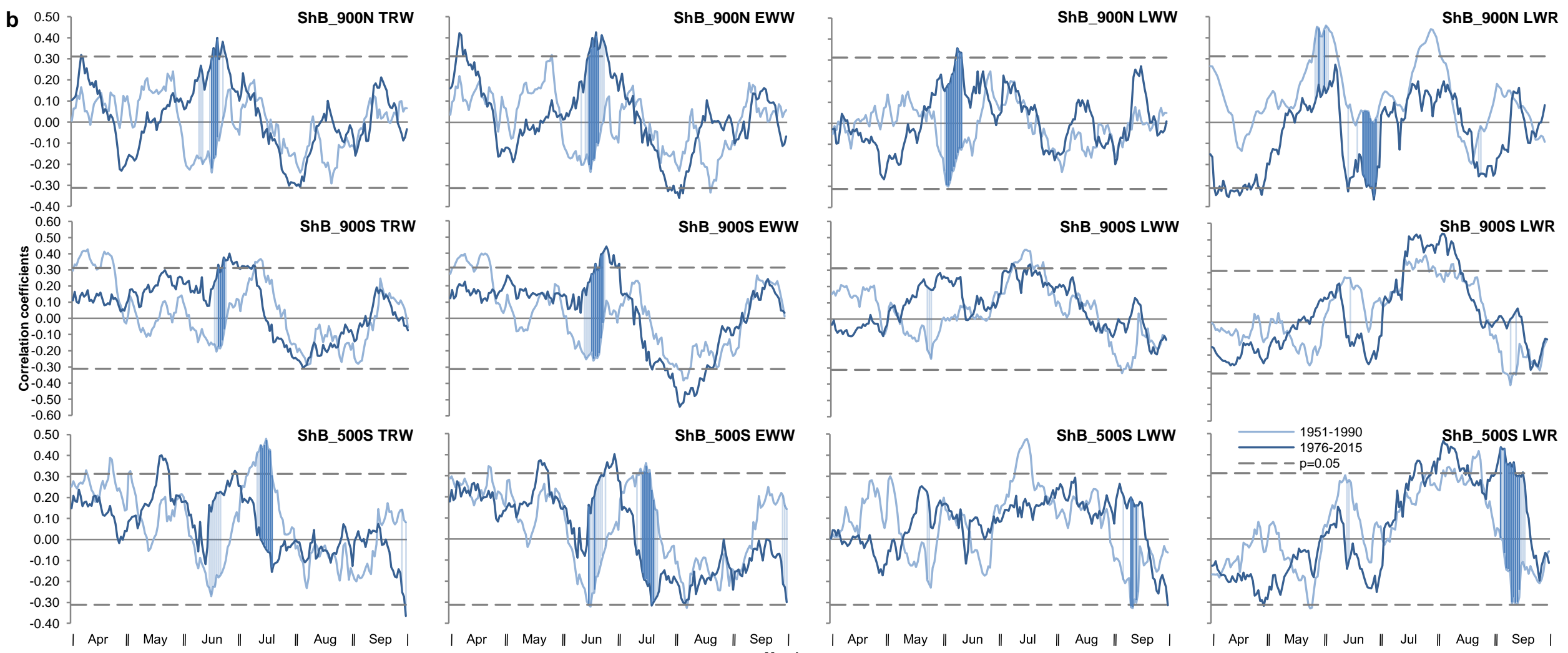

Fig. S6 Correlations between Pinus sylvestris site chronologies of TRW, EWW, LWW, and LWR with moving series (21-day window, 1-day step) of temperature (a) and precipitation (b) derived from daily data of the Cheryomushki station over the 40-year subperiods 1951-1990 (dashed lines) and 1976-2015 (solid lines) from April to September. Significance level of correlations $(\mathrm{p}=0.05$ ) is shown with thin dashed horizontal lines; significance level of differences between correlations over two subperiods are shown with dark $(\mathrm{p}=0.05)$ and light $(\mathrm{p}=0.10)$ vertical lines 